\title{
Gender-Related Differences in Mouse Hepatic Ethanol Metabolism
}

\author{
Ritsuko Kishimoto*, Yasuka Ogishi, Miwa Ueda, Mari Matsusaki, Katumi Amako, \\ Kiyoshi GoDA and Sang-Shin PARK ${ }^{1}$ \\ Faculty of Nutrition, Kobe Gakuin University, Nishi-ku, Kobe 651-2180, Japan \\ ${ }^{1}$ Occupational Diseases Diagnosis and Research Center, 34-6 Kusan-Dong, \\ Pupyeong-ku, Inchon 403-120, Korea
}

(Received November 3, 2001)

\begin{abstract}
Summary The effect of an acute oral load of $2 \mathrm{~g}$ ethanol $/ \mathrm{kg}$ body weight was studied in a group of male and female 10-wk-old $\mathrm{C} 3 \mathrm{H} / \mathrm{HeNCrj}(\mathrm{C} 3 \mathrm{H} / \mathrm{He})$ mice to investigate gender change throughout differences of the hepatic ethanol metabolism of mice. The following parameters were measured in the serum from $0 \mathrm{~h}$ to $3 \mathrm{~h}$ after the start of the experiment: ethanol, acetaldehyde, and acetate. Their concentrations in the serum in female mice tended to show lower levels than in male mice. In female mice, the concentration of ethanol at $1 \mathrm{~h}$ and the concentration of acetate at $1 \mathrm{~h}, 2 \mathrm{~h}$, and $3 \mathrm{~h}$ after ethanol administration showed significantly lower levels than in male mice. Ten-week-old male and female $\mathrm{C} 3 \mathrm{H} / \mathrm{He}$ mice were subcutaneously injected $50 \mu \mathrm{g} / \mathrm{kg}$ body weight $\beta$-estradiol and $1.45 \mathrm{mmol} / \mathrm{kg}$ body weight testosterone propionate (testosterone) in olive oil, respectively, and changes in the activity of enzymes related to the hepatic ethanol metabolism of mice were examined at $24 \mathrm{~h}$ after the administration of sex hormones. The activity of the cytosolic alcohol dehydrogenase $(\mathrm{ADH})$ and microsomal aniline hydroxylase $(\mathrm{ANH})$ and the low $\mathrm{Km}$, high $\mathrm{Km}$ and total aldehyde dehydrogenase (AIDH) activities in the mitochondrial, the cytosolic, and the microsomal fraction of the liver were higher. Moreover, the density of the band of CYP2E1 in the microsome in female mice was stronger than in male mice, and in the microsomal fraction of the liver, the total content of cytochrome P-450 (CYP) and ethoxyresorufin O-dealkylase (EROD) activity in male mice showed significantly higher values than in female mice. The density of the band of CYP2E1 and the three activities of AIDH in the hepatic mitochondrial fraction of male mice increased significantly under treatment with $\beta$-estradiol. The three activities of AIDH of the cytosolic fraction of the liver in female mice significantly decreased under treatment with testosterone. The present findings suggested that in $\mathrm{C} 3 \mathrm{H} / \mathrm{He}$ mice livers, the rate of ethanol metabolism is faster in females than in males, and the enzymes related to ethanol metabolism are controlled by testosterone or $\beta$-estradiol. It is suggested that ethanol and its metabolite disappear faster from the serum of female mice than from the serum of male mice because the activities of hepatic enzymes related to ethanol metabolism are higher in female mice than in male mice.
\end{abstract}

Key Words $\mathrm{C} 3 \mathrm{H} / \mathrm{He}$ mice, hepatic ethanol metabolism, gender different, $\mathrm{ADH}, \mathrm{AlDH}$

Ethyl alcohol (ethanol) is used in alcoholic beverages or as an ingredient in cooking contain. Ethanol is known to be oxidized to acetaldehyde in the liver mainly by two enzyme systems (first stage). One is alcohol dehydrogenase $(\mathrm{ADH})$, present in the cytoplasm (cytosol). The other is the NADPH-dependent microsomal ethanol-oxidizing system (MEOS) (1) by the proliferation of smooth endoplasmic reticulum (microsome). The cytochrome P-450 (CYP) enzyme superfamily constitutes the major oxidative hepatic system for xenobi-

* To whom correspondence should be addressed.

E-mail: kishimot@nutr.kobegakuin.ac.jp

Abbreviations: CYP, cytochrome P-450; ADH, alcohol dehydrogenase; AlDH, aldehyde dehydrogenase; MEOS, microsomal ethanol-oxidizing system; ANH, aniline hydroxylase; EROD, ethoxyresorufin O-dealkylase; MAb, monoclonal antibody. otics, and CYP2E1 which is induced in mice by ethanol exposure, shows high aniline hydroxylase (ANH) activity and is an indispensable factor of MEOS (2). CYP1A2, which is induced by chemical carcinogens such as 3methylcholanthrene in mice liver, also catalyzes MEOS activity (3) and shows ethoxyresorufin O-dealkylase (EROD) (4). Although catalase can be catalyzed to oxidizing ethanol to acetaldehyde in vitro, it appears to play no significant role in ethanol metabolism (5). The second stage of ethanol catabolism in the liver, the irreversible oxidation of acetaldehyde to acetate, is catalyzed by aldehyde dehydrogenase (AIDH). Low Km and high $\mathrm{Km}$ AlDH activities were detected in the mitochondria, microsome, and cytosol fractions of mouse $(6,7)$ and rat $(8)$ liver. It was suggested or reported that low $\mathrm{Km}$ mitochondrial AlDH plays the major role in acetaldehyde metabolism (9). Another study suggested, however, that mouse liver cytosolic AIDH may play a 
leading role in acetaldehyde oxidation in vivo (10). Acetaldehyde plays an important role in the toxic and pharmacological effects of alcohol (11).

Clinical epidemiological studies have suggested that female drinkers of alcohol may be at higher risk of liver disease than males (12). Frezza et al. showed that the bioavailability of ethanol is much greater in women than in men (13). Our previous studies on $\mathrm{C} 3 \mathrm{H} / \mathrm{He}$ male mice have shown that the hepatic enzymes related to the ethanol metabolism differed between mice strains (6).

It was reported that in the ethanol oxidation of AKR, CF\#1, C57BL/6, and NZW mice (14) and rats (15), males were found to be lower than females, and adult Swiss, AKR, C57BL/6, and DBA females exhibited significantly higher levels of hepatic ADH than their male counterparts did, whereas no gender differences were seen in C3H, CBA, and C57Bred (16). Balak et al. reported that developmental expressions of $\mathrm{ADH}$ in high $(\mathrm{C} 57 \mathrm{BL} / 6)$ and low $(\mathrm{C} 3 \mathrm{H}) \mathrm{ADH}$ activity mice have also been investigated (17). It is generally accepted that rat liver ADH activity is known to be significantly lower in males than in females (18), but the activity of gastric ADH involved in the "first-pass alcohol metabolism" was higher in male mice than in female mice (19). The hepatic cytosolic ADH of rats were regulated by sex hormones (18). However, the relations between the activities of $\mathrm{ADH}$ and of ethanol metabolism in mice liver is unknown. Teschke et al. reported that sex hormones such as testosterone and estradiol affect the hepatic MEOS in rats (20), and Lieber and Decarli reported that the activity of the MEOS of male rats was higher than of female rats (21). Gender-related differences were also recognized in the hepatic and renal microsomal CYP2E1-dependent metabolism of steroids (22) and xenobiotics (23) in rats and mice.

The oxidation of acetaldehyde in the liver results in the formation of acetate. There are a few studies about gender differences in the oxidation of acetaldehyde, and acetate metabolism remains unknown. Yamazaki et al. reported that the activities of low $\mathrm{Km}$ and high $\mathrm{Km}$ AlDH of mitochondria, the soluble fraction and microsomes of liver of the C57BL/6J mouse strain, were higher in female mice, except for the low Km of mitochondria at midnight, than in male mice (24). Smolen et al. reported that the mouse liver contains five constitutive AlDH isozymes: high $\mathrm{Km}$ and low $\mathrm{Km}$ of mitochondria, high Km and low Km of cytosol, and high Km of microsomes. They found no gender differences in the developmental profile of AIDH (25). It was reported that phenobarbital induced AIDH in rat (26) and mice (27) livers. Gender differences in the activity of hepatic AIDH are unclarified.

We undertook this study to investigate gender differences in the rate of oxidation of ethanol and acetaldehyde and in the effect of sex hormones on the activities of hepatic enzymes related to ethanol metabolism in mice.

\section{EXPERIMENTAL PROCEDURES}

Animals. Four-week-old male and female $\mathrm{C} 3 \mathrm{H} /$ $\mathrm{HeNCrj}$ (C3H/He) mice were obtained from Japan Charles River Co., Ltd. They were fed commercial MF food (Oriental Yeast Co., Ltd.) with water ad libitum and housed for $6 \mathrm{wk}$.

Two parts of an experiment were carried out: (1) A comparison of male and female mice on time course changes in the concentrations of ethanol, acetaldehyde, and acetate in the serum after oral ethanol administration. (2) The effects of testosterone or $\beta$-estradiol on hepatic enzymes related to ethanol metabolism.

For experiment (1), ten-wk-old male and female $\mathrm{C} 3 \mathrm{H} / \mathrm{He}$ mice were food-deprived overnight, then orally administered $2 \mathrm{~g}$ of ethanol $(0.01 \mathrm{~mL}$ of $20 \%(\mathrm{w} / \mathrm{v})$ ethanol solution) $/ \mathrm{kg}$ body weight with a disposable feeding needle at 9 a.m. and sacrificed by cervical dislocation after $1 \mathrm{~h}$ (10 a.m.), $2 \mathrm{~h}$ (11 a.m.), or $3 \mathrm{~h}$ (noon). Male and female mice not administered ethanol $(\mathrm{O} h)$ were sacrificed by cervical dislocation. The serum was collected immediately and prepared for assaying the concentrations of ethanol, acetaldehyde, and acetate.

For experiment (2), ten-wk-old male and female $\mathrm{C} 3 \mathrm{H} / \mathrm{He}$ mice were subcutaneously injected $50 \mu \mathrm{g} / \mathrm{kg}$ body weight $\beta$-estradiol (Sigma Chemical Co. Ltd.) and $1.45 \mathrm{mmol} / \mathrm{kg}$ body weight testosterone propionate (testosterone) (Nacalai Tesque) in olive oil, respectively. Other groups of male and female mice were administered $0.1 \mathrm{~mL}$ of olive oil (control group). Each mice group at $24 \mathrm{~h}$ after the administration of sex hormones was sacrificed by cervical dislocation, and the liver was removed immediately and weighed to determine various enzyme activities. All livers were stored at $-70^{\circ} \mathrm{C}$ until use.

Determinations of ethanol, acetaldehyde, and acetate concentrations in serum. The concentrations of ethanol, acetaldehyde, and acetate in the serum were determined by the enzyme method with an Ethanol UV Test, F-kit Acetaldehyde, or F-kit Acetate, respectively (Boehringer Mannheim Biochemica).

Cell fractions. Liver cell fractionation was performed by differential centrifugation, as described previously $(6,7)$. Each fraction was kept at $-70^{\circ} \mathrm{C}$ until it was assayed for enzyme activity.

Measurements of enzyme activities. Cytosolic ADH activity was assayed as described previously $(6,7)$. The activities of MEOS and ANH in the microsomal fraction were assayed according to the method of Klein et al. (28), and Brodie and Axelrod (29), respectively. The activities of EROD in the microsome were assayed according to the method of Cai et al. (30) and Burke and Mayer (4). The activities of AIDH in the three cell fractions were assayed by the method of Lebsack et al. (8), except that the acetaldehyde concentrations were $5 \mathrm{~mm}$ for total, $300 \mu \mathrm{M}$ for high $\mathrm{Km}$, and $50 \mu \mathrm{M}$ for low $\mathrm{Km}$ enzymes.

Immunoblot analysis. Western blotting of the hepatic microsomal protein $(50 \mu \mathrm{g})$ was performed as de- 

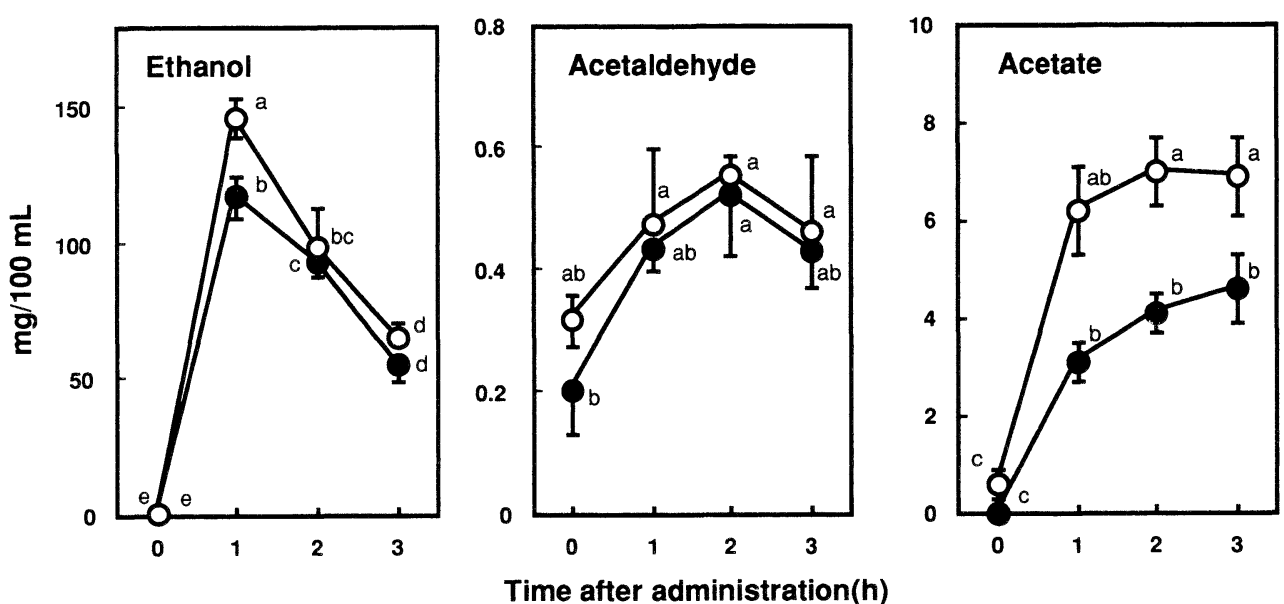

Fig. 1. Changes in the concentrations of ethanol, acetaldehyde, and acetate in serum of male $(\bigcirc)$ and female $(\bullet)$ mice after oral ethanol administration. Values (means \pm SE of 6 mice) not bearing the same superscript or subscript letters are significantly different from one another $(p<0.05)$. Among the experimental groups, the letter "a" indicates the highest value with the descending order of " $b$ " and "c."

scribed previously $(6,7)$. Mouse monoclonal antibody (MAb) 1-98-1 to rat CYP2E1 (31), mouse MAb 1-7-1 to rat CYP1A1, and $1 A 2$ (32) and mouse MAb 1-31-1 to rat CYP1A1 (32) were used as primary antibodies. A densitometric analysis of the bands after Western blotting was performed with a PDI Image Analyzer (Pharmacia Biotech).

Other assay methods. Total microsomal CYP content was determined from the CO-reduced difference spectrum in $0.1 \mathrm{M}$ potassium phosphate buffer (33). The protein contents in the cell fractions were measured by the biuret method (34) with bovine serum albumin (Sigma Chemical Co., Ltd.) as the standard.

Statistical analysis. The values were expressed as means \pm SE. The differences among them were analyzed by use of the analysis of variance (ANOVA) coupled with Duncan's new multiple-range test (35) and were considered significant at $p<0.05$.

\section{RESULTS}

Changes in the concentrations of ethanol, acetaldehyde, and acetate in the serum

The time course changes in the concentrations of ethanol, acetaldehyde, and acetate in the serum after an oral administration of $2 \mathrm{~g}$ ethanol $/ \mathrm{kg}$ are shown in Fig. 1. The peak values of the concentration of ethanol were reached after $1 \mathrm{~h}$ and were significantly lower in female mice $(117 \pm 7 \mathrm{mg} / 100 \mathrm{~mL})$ than in male mice $(147 \pm 7 \mathrm{mg} / 100 \mathrm{~mL})$. The ethanol concentration in the serum decreased at $2 \mathrm{~h}$ and $3 \mathrm{~h}$ later and were lower in female mice than in male mice. The concentration of acetaldehyde in the serum of male and female mice increased after ethanol administration. The peak values of the concentration of acetaldehyde in the serum at $2 \mathrm{~h}$ after ethanol administration was $0.56 \pm 0.03 \mathrm{mg} / 100$ $\mathrm{mL}$ in male mice and $0.53 \pm 0.10 \mathrm{mg} / 100 \mathrm{~mL}$ in female mice, though there were no significant differences between the male and female mice. The concentrations of acetate in serum of the male and the female mice were significantly increased at $1 \mathrm{~h}, 2 \mathrm{~h}$, and $3 \mathrm{~h}$ after ethanol
Table 1. Activities of cytosolic ADH in the liver of male and female mice treated with $\beta$-estradiol and testosterone propionate, respectively.

\begin{tabular}{cc}
\hline Gender and treatment & $\begin{array}{c}\mathrm{ADH} \\
(\mathrm{NADH} \mu \mathrm{mol} / \mathrm{min} / \mathrm{mg} \text { prot. })\end{array}$ \\
\hline Male & $6.20 \pm 0.14^{\mathrm{bc}}$ \\
Control & $5.97 \pm 0.15^{\mathrm{c}}$ \\
$\beta$-Estradiol & \\
Female & $6.65 \pm 0.13^{\mathrm{a}}$ \\
Control & $6.43 \pm 0.11^{\mathrm{ab}}$ \\
Testosterone & \\
\hline
\end{tabular}

Values (means \pm SE of 9 mice) not bearing the same superscript or subscript letters are significantly different from one another $(p<0.05)$. Among the experimental groups, the letter " $a$ " indicates the highest value with the descending order of "b" and "c."

administration. The increases in the acetate concentration in the serum in female mice $(3.1 \pm 0.4-4.6 \pm$ $0.7 \mathrm{mg} / 100 \mathrm{~mL}$ ) were always significantly lower than in the male mice $(6.2 \pm 0.9-6.9 \pm 0.8 \mathrm{mg} / 100 \mathrm{~mL})$ at $1 \mathrm{~h}, 2 \mathrm{~h}$, and $3 \mathrm{~h}$ after the ethanol administration.

Activities of ADH in the hepatic cytosols

As shown in Table 1 , the activity of $\mathrm{ADH}(\mu \mathrm{mol} /$ $\mathrm{min} / \mathrm{mg}$ prot) of the hepatic cytosolic fraction was higher in female mice $(6.65 \pm 0.13)$ than in male mice $(6.20 \pm 0.14)$, though these activities of the male and female mice did not change as a result of treatment with $\beta$-estradiol and testosterone, respectively.

Activities of MEOS, ANH, and EROD and contents of CYP in the hepatic microsomes

As shown in Table 2, no difference in the activities of MEOS was recognized between the control groups of male and female mice, but the content of CYP (nmol/mg prot) was significantly higher in male mice $(0.546 \pm 0.024)$ than in female mice $(0.431 \pm 0.021)$. The activities of MEOS and the contents of CYP of male and female mice did not change as a result of treatment 
Table 2. Activities of MEOS and ANH and the contents of CYP of hepatic microsomes of male and female mice treated with $\beta$-estradiol and testosterone, respectively.

\begin{tabular}{ccccc}
\hline $\begin{array}{c}\text { Gender and } \\
\text { treatment }\end{array}$ & $\begin{array}{c}\text { MEOS } \\
(\mathrm{nmol} / \mathrm{min} / \mathrm{mg} \text { prot. }) \\
n=6\end{array}$ & $\begin{array}{c}\text { CYP } \\
(\mathrm{nmol} / \mathrm{mg} \text { prot. }) \\
n=5\end{array}$ & $\begin{array}{c}\text { ANH } \\
(\mathrm{nmol} / \mathrm{min} / \mathrm{mg} \text { prot. }) \\
n=6\end{array}$ & $\begin{array}{c}\text { EROD } \\
\text { (pmol/min/mg prot. }) \\
n=5\end{array}$ \\
\hline $\begin{array}{c}\text { Male } \\
\text { Control }\end{array}$ & $1.25 \pm 0.11$ & $0.546 \pm 0.024^{\mathrm{a}}$ & $0.277 \pm 0.034$ & $15.84 \pm 0.64^{\mathrm{a}}$ \\
$\quad \begin{array}{l}\text {-Estradiol } \\
\text { Female }\end{array}$ & $1.35 \pm 0.10$ & $0.566 \pm 0.019^{\mathrm{a}}$ & $0.352 \pm 0.016$ & $15.82 \pm 1.29^{\mathrm{a}}$ \\
$\quad$ Control & $1.27 \pm 0.15$ & $0.431 \pm 0.029^{\mathrm{b}}$ & $0.363 \pm 0.022$ & $10.93 \pm 0.27^{\mathrm{b}}$ \\
Testosterone & $1.30 \pm 0.13$ & $0.421 \pm 0.021^{\mathrm{b}}$ & $0.333 \pm 0.024$ & $12.56 \pm 0.70^{\mathrm{b}}$ \\
\hline
\end{tabular}

Values (means \pm SE) not bearing the same superscript or subscript letters are significantly different from one another $(p<0.05)$. Among the experimental groups, the letter "a" indicates the highest value with the descending order of " $\mathrm{b}$ " and "c."

\section{EtOH 1-98-1 (MAb to CYP2E1) MC 1-7-1
(MAb to CYP1A1,1A2)}

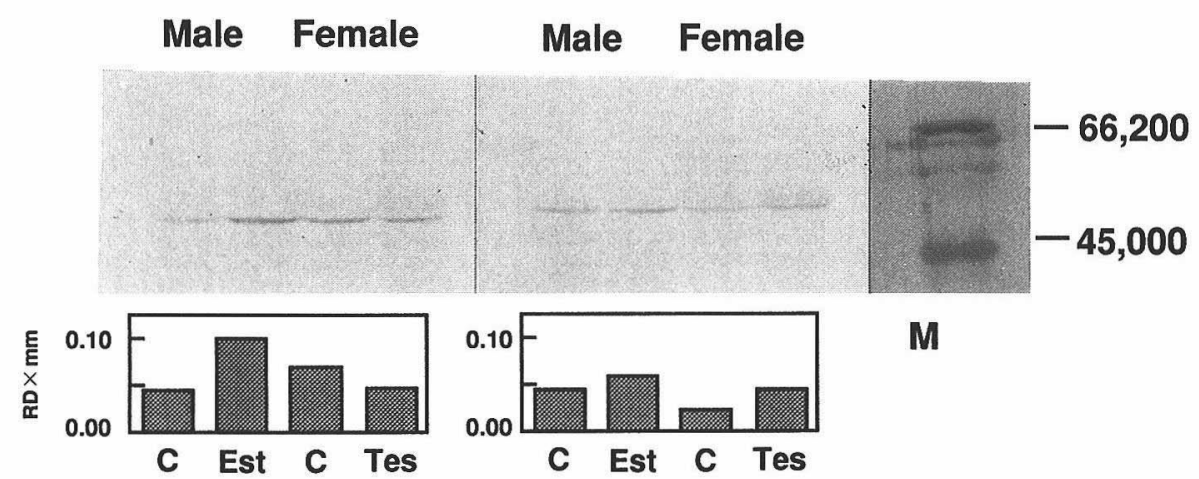

Fig. 2. Western blot analysis of CYP2E1 (left, upper panel) and CYP1A1 and 1A2 (right, upper panel). Hepatic microsomal proteins $(50 \mu \mathrm{g})$ of male and female mice treated with $\beta$-estradiol (Est) and testosterone propionate (Tes), respectively, and control $(\mathrm{C})$ were analyzed by immunoblot analysis by the use of monoclonal antibodies (MAb) against EtOH 1-98-1 (left) and MC 1-7-1 (right). A densitometric analysis is shown in the lower graphs, respectively, and the intensity of each band was measured by a PDI Image Analyzer.

with sex hormones. In the control group, the activity of ANH tended to be higher in female mice than in male mice, but the activity of EROD ( $\mathrm{pmol} / \mathrm{min} / \mathrm{mg}$ prot) was significantly higher in male mice $(15.84 \pm 0.64)$ than in female mice $(10.93 \pm 0.27)$. The activity of the ANH of male mice tended to increase by the treatment with $\beta$ estradiol, but the activity of the EROD of female mice tended to increase by the treatment with testosterone. Immunoblot analysis of the hepatic microsomal proteins

The detection of CYP2E1 was carried out with MAb 1-98-1. As shown in Fig. 2 (left, upper panel), the immunoreactive bands of CYP2E1 were observed in all hepatic microsome preparations. The intensity of the CYP2E1 band was stronger in female mice than in male mice and decreased after treatment with testosterone; that of male mice increased after treatment with $\beta$ estradiol (left, lower graph). The detection of CYP1A1 and $1 A 2$ was carried out with MAb 1-7-1. As shown in Fig. 2 (right, upper panel), the immunoreactive bands of CYP1A2 were observed in all hepatic microsome preparations. The CYP1A1 band was not detected in any hepatic microsomes of mice because MAb 1-31-2 did not react with any proteins in the hepatic microsomes (data not shown). The intensity of the CYP1A2 band was stronger in male mice than in female mice and increased in female mice after treatment with testosterone (right, lower graph).

Activities of AlDH in the hepatic mitochondria

The AIDH activities of the hepatic mitochondrial fraction of male and female mice are shown in Fig. 3. In the control mice group, the low $\mathrm{Km}$, high $\mathrm{Km}$, and total AIDH activities (nmol/min/mg prot) were higher in female mice $(12.16 \pm 0.65,13.02 \pm 0.84$, and $16.51 \pm$ 0.51 , respectively) than in male mice $(8.12 \pm 1.07$, $9.73 \pm 1.07$, and $12.21 \pm 0.81$, respectively). Especially, the low $\mathrm{Km}$ and total AlDH activities were significantly higher in female mice than in male mice. The low Km AIDH activity of the male mice was significantly increased and the high $\mathrm{Km}$ and the total AIDH activities tended to increase after treatment with $\beta$-estradiol, though these activities of female mice did not change after treatment with testosterone.

Activities of AIDH in the hepatic microsomes

The activities of the hepatic microsomal fraction of 


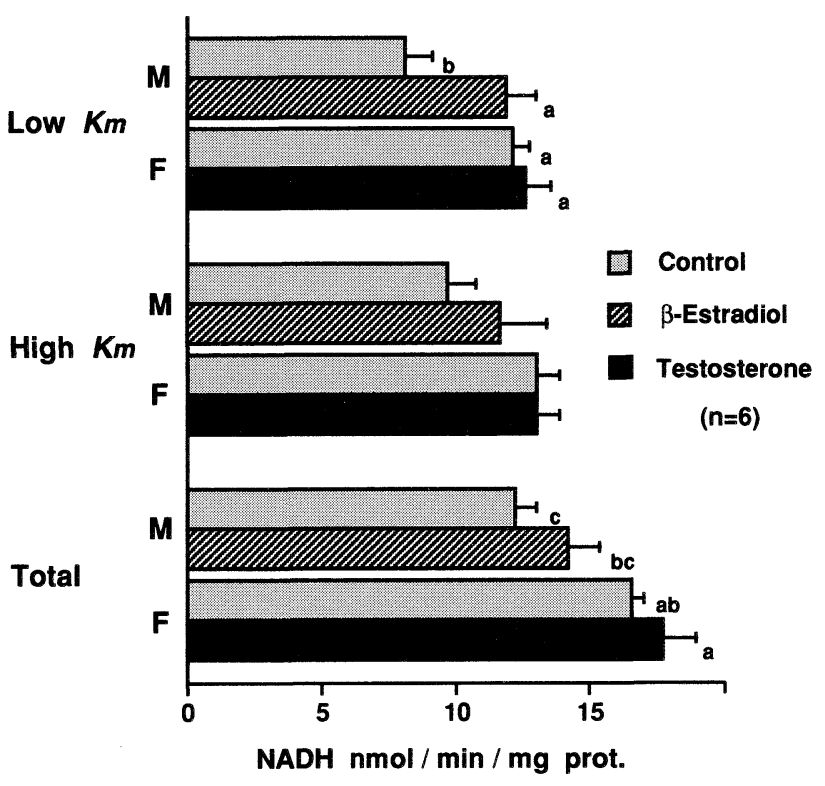

Fig. 3. Activities of the AlDHs in the hepatic mitochondria of male $(\mathrm{M})$ and female (F) mice treated with $\beta$-estradiol and testosterone propionate, respectively. Values (means \pm SE) not bearing the same superscript or subscript letters are significantly different from one another $(p<0.05)$. Among the experimental groups, the letter "a" indicates the highest value with the descending order of "b" and "c."

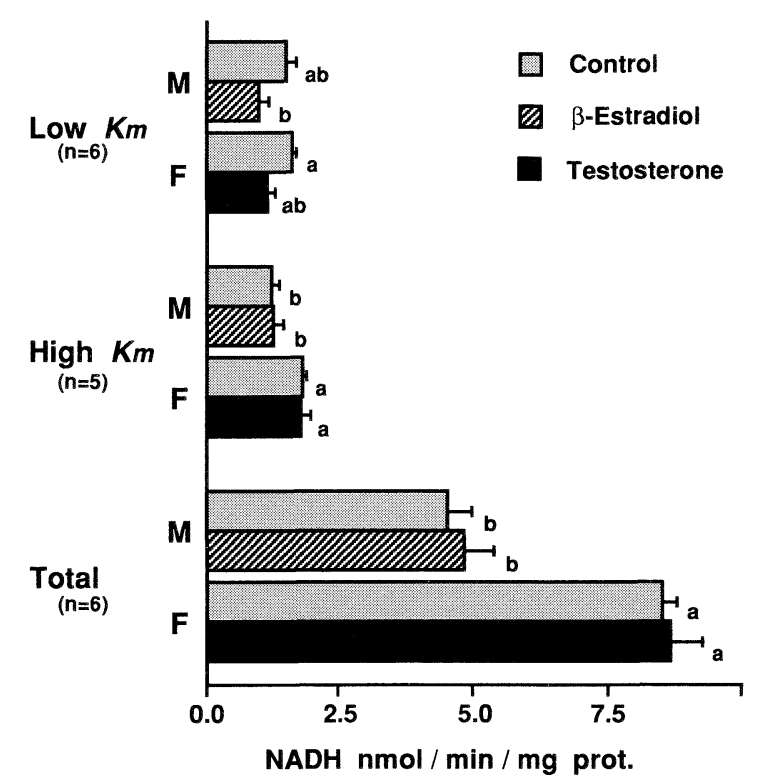

Fig. 4. Activities of the AlDHs in the hepatic microsome of male $(\mathrm{M})$ and female $(\mathrm{F})$ mice treated with $\beta$ estradiol and testosterone propionate, respectively. Values (means \pm SE) not bearing the same superscript or subscript letters are significantly different from one another $(p<0.05)$. Among the experimental groups, the letter "a" indicates the highest value with the descending order of "b" and "c."

male and female mice are shown in Fig. 4. In the control mice group, the high $\mathrm{Km}$ and the total AIDH activities $(\mathrm{nmol} / \mathrm{min} / \mathrm{mg}$ prot) were significantly higher in female mice $(1.83 \pm 0.08$ and $8.52 \pm 0.27$, respectively)

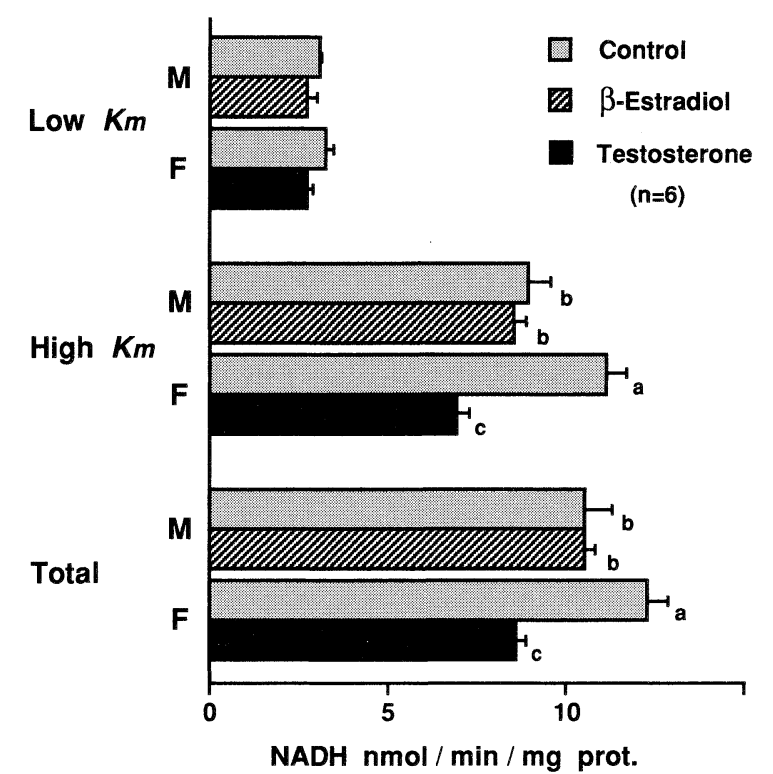

Fig. 5. Activities of the AlDHs in the hepatic cytosol of male $(\mathrm{M})$ and female $(\mathrm{F})$ mice treated with $\beta$-estradiol and testosterone propionate, respectively. Values (means \pm SE) not bearing the same superscript or subscript letters are significantly different from one another $(p<0.05)$. Among the experimental groups, the letter "a" indicates the highest value with the descending order of "b" and "c."

than in male mice $(1.25 \pm 0.15$ and $4.53 \pm 0.47$, respectively). The low Km, high Km, and total AlDH activities did not change in male mice and female mice, and also following sex hormone treatment.

Activities of AIDH in the hepatic cytosols

The activities of the hepatic cytosolic fraction of male and female mice are shown in Fig. 5. In the control mice group, the high $\mathrm{Km}$ and the total AIDHs activities (nmol/min $/ \mathrm{mg}$ prot) were significantly higher in female mice (11.11 \pm 0.60 and $12.30 \pm 0.57$, respectively) than in male mice $(8.96 \pm 0.62$ and $10.54 \pm 0.75$, respectively). These two AIDH activities of female mice decreased as a result of treatment with testosterone; those of male mice did not change after treatment with $\beta$ estradiol.

\section{DISCUSSION}

The aim of the present study was to investigate the gender differences in hepatic ethanol metabolism and the effects of sex hormones on enzymes involved in the hepatic ethanol metabolism of mice. It is generally accepted that the mammalian liver contains three pathways for ethanol oxidation, i.e., the ADH pathway in the cytosol, the MEOS in the microsome, and the catalase system in the peroxisome. The catalase activity was not measured in this study. Each of these pathways results in the production of acetaldehyde, which is then metabolized into acetate. The concentrations of ethanol, acetaldehyde, and acetate in the serum were always lower in female mice than in male mice after oral ethanol administration (Fig. 1). The ethanol concentration at $1 \mathrm{~h}$ after oral ethanol administration and 
the acetate concentration at $1 \mathrm{~h}, 2 \mathrm{~h}$, and $3 \mathrm{~h}$ after oral ethanol administration showed significant differences between male mice and female mice. These results suggest that in the $\mathrm{C} 3 \mathrm{H} / \mathrm{He}$ mice strain, the rates of disappearance of ethanol, acetaldehyde, and acetate from the serum after oral ethanol administration is faster in female mice than in male mice. Sudo (14) reported that the disappearance of ethanol from the serum in mice strains CF\#, AKR, C57BL, and NZY was faster in females than in males. In the present study, the same results were obtained in the $\mathrm{C} 3 \mathrm{H} / \mathrm{He}$ mice strain. However, Desroches et al. (19) reported that higher blood alcohol levels were found in all intubated females (C57BL and DBA) compared to the intubated males. The amount of ethanol administration $(2 \mathrm{~g} / \mathrm{kg} \mathrm{BW})$ in this study was less than $3.75 \mathrm{~g} / \mathrm{kg}$ BW in them. It is well known that alcoholic liver disease develops more readily in women than men. Frezza et al. (13) reported that after consuming comparable amounts of ethanol, women had higher blood ethanol concentration than men, and in nonalcoholic subjects, gastric ADH activity (first-pass metabolism) of the women was 59\% of what it was in the men. The levels of gastric $\mathrm{ADH}$ differ among ethnic groups. An $\mathrm{ADH}$ isozyme $(\sigma-\mathrm{ADH})$, which is present in gastric mucosa but not in the liver, is absent or markedly decreased in $80 \%$ of Japanese persons (36). For a given amount of alcohol consumed, blood levels are higher in women than in men for two reasons: the smaller body size of women and the distribution of alcohol in a smaller water space in women because of their higher proportion of fat (11). It was reported that gastric ADH activity was higher in male mice than in female mice $(19,37)$. Future studies will be carried out to examine the sex difference of first-pass alcohol metabolism in $\mathrm{C} 3 \mathrm{H} / \mathrm{He}$ mice strain.

The activities of enzymes related to ethanol metabolism in mice liver were determined and the effect of sex hormones on these hepatic enzymes in mice were examined. Cytosolic ADH, which plays the most important role in the ethanol oxidation of liver, showed significantly higher activities in female mice than in male mice (Table 1). It appeared that a higher activity of $\mathrm{ADH}$ in female mice than in male mice was due to a higher oxidation of ethanol in female mice than in male mice. However, $\beta$-estradiol did not increase the ADH in male mice, and testosterone did not decrease the same enzyme in female mice. Harada et al. (18) reported that the administration of testosterone in rat $(5 \mathrm{mg} / \mathrm{kg}$ body weight, twice a day for $7 \mathrm{~d}$ ) decreased ADH activities, and the administration of $\beta$-estradiol $(50 \mathrm{mg} / \mathrm{kg}$ body weight, once every $2 \mathrm{~d}$ for $20 \mathrm{~d}$ ) increased the ADH activities in males more than in females. In the present experiment, it appeared that small amounts of testosterone to female mice (once, $1.45 \mathrm{mmol} / \mathrm{kg} \mathrm{BW}$ ), or $\beta$ estradiol to male mice (once, $50 \mathrm{mg} / \mathrm{kg} \mathrm{BW}$ ) were administered in smaller amounts than those in Harada et al.

MEOS, another pathway from ethanol to acetaldehyde in the hepatic microsomes, showed similar activities in the male and female mice and did not change as a result of treatment with sex hormones. The contents of CYP and the EROD activities in the hepatic microsomal fraction, however, showed higher activities in male mice than in female mice (Table 2). The ANH in hepatic microsomes of female mice tended to be higher than in male mice, in which it tended to increase as a result of $\beta$-estradiol, though no significant differences were noted between the MEOS activities of the male mice and the female mice (Table 2). The EROD activities in female mice tended to increase after treatment with testosterone. CYP2E1, which is an indispensable component of MEOS, showed high ANH activity (2). CYP2E1 also showed high microsomal $N$-nitrosodimethylamine (NDMA) demethylase levels. It was regulated by testosterone in the renal mouse microsome (23) and was inhibited by diallyl sulfide (DAS) (38). NDMA is a potent hepatocarcinogen. The intensity of the CYP2E1 band in female mice was stronger than in male mice and decreased as a result of treatment with testosterone (Fig. 2 , left). The intensity of the CYP2E1 band in male mice increased after treatment with $\beta$-estradiol. These results suggest that the depressed increase in ethanol in the serum of female mice was due to the high ADH activities in hepatic cytosol and the CYP2E1 which was controlled by sex hormones, in the hepatic microsome. CYP1A2 and CYP1A1 belong to the CYP1A family, which consists of a metabolically active large number of procarcinogens and reactive intermediates that can interact with cellular nucleophiles and ultimately trigger carcinogenesis (39). The induction of CYP1A1 and CYP1A2 is associated with various cancers (40). CYP1A1 generally metabolizes polycyclic aromatic hydrocarbons, whereas CYP1A2 activates aminofluorenes and nitrosamines (41). Moreover, CYP1A2 metabolizes important drugs such as theophylline, caffeine, imipramine, and propanol. Kunitoh et al. reported that CYP1A2 also augmented MEOS activity (3) and shows high EROD activities (4). The CYP1A2 (Fig. 2 , right) was also detected in hepatic microsomes of the male and female mice, though the CYP1A1 was not detected in microsomes from either gender. The CYP1A2 in the male mice was higher than in the female mice, in which it increased after treatment with testosterone. It appeared that CYP1A2 in the hepatic microsomes of $\mathrm{C} 3 \mathrm{H} / \mathrm{He}$ mice was gender-dependent in hepatic cells.

Women have higher ethanol-induced aldehyde levels than men do (42). Acetaldehyde is derived from ethanol though aerobic oxidation by $\mathrm{ADH}$ and is typically rapidly metabolized to acetate by AIDH. Consequently, the acetaldehyde concentrations observed in the blood after ethanol ingestion are generally very low. Acetaldehyde in the serum tended to increase $1 \mathrm{~h}$ and $2 \mathrm{~h}$ after ethanol administration and to decrease $3 \mathrm{~h}$ after. It also tended to be lower in female mice than in male mice, though there were no significant differences between the male and female mice or between the time after ethanol administration. The gender-difference blood acetaldehyde levels of $\mathrm{C} 3 \mathrm{H} / \mathrm{He}$ mice strain were not confirmed be the same as those of humans. The activities of hepatic mitochondrial AlDHs were higher in female 
mice than in male mice (Fig. 3). The hepatic mitochondrial low $\mathrm{Km}$, which is the most important enzyme in acetaldehyde metabolism of the liver, and total AlDHs in the female mice showed significantly higher activities than in male mice. The activities of low $\mathrm{Km}$, high $\mathrm{Km}$, and total $\mathrm{AlDH}$ in the mitochondria of male mice livers increased as a result of treatment with $\beta$-estradiol, whereas the activities of low $\mathrm{Km}$ and high $\mathrm{Km}$ AIDH in the mitochondria in female mice did not change after treatment with testosterone. Hepatic cytosolic AIDH also showed higher activities in female mice than in male mice (Fig. 4). There were significant differences in high $\mathrm{Km}$ and total AIDH activities between male and female mice. These two activities of the cytosolic fraction in female mice decreased as a result of treatment with testosterone, but in male mice it did not change after treatment with $\beta$-estradiol. Moreover, the high $\mathrm{Km}$ and the total AIDH in the hepatic microsomes in the female mice showed higher activity than in the male mice (Fig. 5). The hepatic microsomal low $\mathrm{Km}$, high $\mathrm{Km}$, and total AIDH did not change in the male or female mice after treatment with testosterone or $\beta$-estradiol, respectively. In the three fractions, the mitochondria, the microsomes, and the cytosols of the control groups of male and female mice, the low $\mathrm{Km}$, the high $\mathrm{Km}$, and the total AIDH activities were similar or higher in female mice than in male mice. It appeared that the oxidation of acetaldehyde to acetate was higher in female mice than in male mice, though the contents of aldehyde in serum after ethanol administration were not significantly different between female and male mice. Twelve AIDH genes have been identified in various tissues of human, such as liver, kidney, stomach, lung, brain, heart, and muscle (43). Maly et al. reported that sex differences were not detected either in activity or in distribution pattern (44). However, the gender-related difference and the role of these AlDHs in ethanol and acetaldehyde metabolism is unknown, and the mechanism of acetaldehyde metabolism is still unclear. Kunitoh et al. (45) reported that CYP2E1 had the highest oxidation activity and CYP1A2 and CYP4A2 the next highest activity of NADPH-dependent activity of acetaldehyde oxidation, similar to the microsomal acetaldehyde-oxidizing system in rat liver. Aldehyde oxidase in cytosol and microsomes and microsomal aldehyde oxygenase (MALDO), mainly catalyzed by CYP2C29 in microsomes (46), were not determined in the present study. It was also reported that CYP2E1 in rats is an aldehyde oxidase (47).

Hannak et al. reported that acetate in the serum of men showed $0.45-0.62 \mathrm{~mm}$ at $1-4 \mathrm{~h}$ after ethanol administration; it then decreased and was higher in females than in males (48). In the present study, however, the acetate in the serum after the oral ethanol administration disappeared faster in female mice than in male mice. It is known that acetate in the serum is generally metabolized into acetyl-CoA and then into water and $\mathrm{CO}_{2}$ from the tricarboxylic acid cycle in the liver and the muscle tissue. Acetyl-CoA is also metabolized into fatty acid, acetone, $\beta$-hydroxybutyrate, or cholesterol. The blood acetate concentration following alcohol consumption has been suggested as a marker for the increased alcohol metabolism seen in alcoholics or habitual heavy drinkers (49). However, the relation between the rate of alcohol metabolism and blood acetate concentration is complicated. Acetate metabolism is not yet known in detail.

These results suggest that gender differences exist in the ethanol metabolism of mice livers. It is suggested that ethanol, acetaldehyde, and acetate are metabolized faster in female mice than in male mice from serum because the activities of hepatic enzymes related to the oxidation of ethanol and acetaldehyde are higher in female mice than in male mice. In conclusion, the rate of ethanol metabolism in $\mathrm{C} 3 \mathrm{H} / \mathrm{He}$ mice livers is faster in females than in males, and the enzymes related to ethanol metabolism is controlled by sex hormones (testosterone or $\beta$-estradiol). It is necessary to examine the interaction of enzyme-related ethanol metabolism in the stomach and the liver and the changes of levels of ethanol, acetaldehyde, and acetate in the serum of chronic ethanol-administered male and female mice.

\section{REFERENCES}

1) Lieber CS, DeCarli LM, Matsuzaki S, Ohnishi K, Teschke R. 1997. The microsomal ethanol oxidizing system (MEOS). In: Biomembranes, Selected Methods in Enzymology Series (Packer L, Fleischer S, eds), p 329-341. Academic Press, New York and London.

2) Koop DR, Morgan ET, Tarr GE, Coon MJ. 1982. Purification and characterization of a unique isozyme of cytochrome P-450 from liver microsomes of ethanoltreated rabbits. J Biol Chem 257: 8472-8480.

3) Kunitoh S, Tanaka T, Imaoka S, Funae Y, Monna Y. 1993. Contribution of cytochrome P450s to MEOS (microsomal ethanol-oxidizing system): A specific and sensitive assay of MEOS activity by HPLC with fluorescence labeling. Alcohol Alcohol 28: 63-68.

4) Burke MD, Mayer RT. 1974. Ethoxyresolufin: Direct fluorometric assay of a microsomal o-dealkylation which is preferentially inducible by 3-methylcholanthrene. Drug Metab Disp 2: 583-588.

5) Teschke R, Hasumura Y, Lieber CS. 1976. Hepatic ethanol metabolism: respective roles of alcohol dehydrogenase, the microsomal ethanol-oxidizing system and catalase. Arch Biochem Biophys 175: 635-643.

6) Kishimoto R, Fujiwara I, Kitayama S, Goda K, Nakata Y. 1995. Changes in hepatic enzyme activities related to ethanol metabolism in mice following chronic ethanol administration. J Nutr Sci Vitaminol 41: 527-543.

7) Kishimoto R, Ueda M, Yoshinaga H, Goda K, Park SS. 1999. Combined effects of ethanol and garlic on hepatic ethanol metabolism in mice. J Nutr Sci Vitaminol 45: $275-286$.

8) Lebsack ME, Gordon ER, Lieber CS. 1981. Effect of chronic ethanol consumption on aldehyde dehydrogenase activity in the baboon. Biochem Pharmacol 30: 2273-2277.

9) Shirota FN, DeMaster EG, Nagasawa H. 1982. Studies of the cyanamide-ethanol interaction. Dimethylcyanamide as an inhibitor of aldehyde dehydrogenase in vivo. Biochem Pharmacol 31: 1999-2004.

10) Smolen A, Atkinson N, Petersen DR. 1980. The role of 
liver cytosolic aldehyde dehydrogenase in ethanol metabolism in DBA and C57B1 mice. Adv Exp Med Biol 132: $627-634$.

11) Lieber CS. 1995. Medical disorders of alcoholism. N Eng J Med 333: 1058-1065.

12) Morgan MY, Sherlock S. 1977. Sex-related difference among 100 patients with alcoholic liver disease. $\mathrm{Br}$ Med J 1: 939-941.

13) Frezza M, Padova C, Pozzato G, Terpin M, Baraona E, Lieber CS. 1990. High blood alcohol levels in women: The role of decreased gastric alcohol dehydrogenase activity and first-pass metabolism. $N$ Eng J Med 322: 95-99.

14) Sudo T. 1981. Study on fluctuating factors in alcohol metabolism-Differences in ethanol oxidation and $\mathrm{ADH}$ activity among mouse strains and between the sexes-. Nichidai Igaku Zasshi (J Nihon Univ Med Assoc) 40: 237-248 (in Japanese).

15) Eriksson K. 1968. Genetic selection for voluntary alcohol consumption in the albino rat. Science 159: 739-741.

16) Rao UN, Aravindakshan M, Satyanarayan V, Chauhan PS. 1997. Genotype- and gender-dependent hepatic alcohol dehydrogenase $(\mathrm{ADH})$ activity in developing mice. Alcohol 14: 527-531.

17) Balak KJ, Kieth RH, Felder MR. 1982. Genetic and developmental regulation of mouse liver alcohol dehydrogenase. J Biol Chem 257: 15000-15007.

18) Harada S, Tachiyashiki K, Imaizumi K. 1998. Effect of sex hormones on rat liver cytosolic alcohol dehydrogenase activity. J Nutr Sci Vitaminol 44: 625-639.

19) Desroches D, Orevillo C, Verina D. 1995. Sex- and strain-related differences in first-pass alcohol metabolism in mice. Alcohol 12: 221-226.

20) Teschke R, Heymann K. 1982. Effect of sex-hormones on the activities of hepatic alcohol-metabolizing enzymes in male rats. Enzyme 28: 268-277.

21) Lieber CS, DeCarli LM. 1970. Hepatic microsomal ethanol oxidizing system. In vitro characteristics and adaptive properties in vivo. $J$ Biol Chem 245: 2505-2512.

22) Pan J, Hong JY, Yang CS. 1992. Post-transcriptional regulation of mouse renal cytochrome P-4502E1 by testosterone. Arch Biochem Biophys 299: 110-115.

23) Hu JJ, Lee MJ, Vpiwala M, Reuhl K, Thomas PE, Yang CS. 1993. Sex-related differences in mouse renal metabolism and toxicity of acetaminophen. Toxicol Appl Pharmacol 122: 16-26.

24) Yamazaki H, Nishiguchi K, Miyamoto R, Nakanishi S. 1985. Circadian rhythms in the activities of brain and liver aldehyde dehydrogenase isozymes in mice. Life Sci 38: $515-520$.

25) Smolen TN, Smolen A, Kamp JL. 1990. Developmental profile of hepatic alcohol and aldehyde dehydrogenase activities in long-sleep and short-sleep mice. Alcohol 7: 69-74.

26) Dunn TJ, Koleske AJ, Lindahl R, Pitot HC. 1989. Phenobarbital-inducible aldehyde dehydrogenase in the rat. cDNA sequence and regulation of the mRNA by phenobarbital in responsive rats. J Biol Chem 264: 13057-13065.

27) Damon M, Fautrel A, Guillouzo A, Corcos L. 1996. Genetic analysis of the phenobarbital regulation of the cytochrome P-450 2b-9 and aldehyde dehydrogenase type 2 mRNAs in mouse liver. Biochem J 317:
$481-486$.

28) Klein SM, Gohen G, Lieber CS, Cederbaum AI. 1983. Increased microsomal oxidation of hydroxyl radical scavenging agents and ethanol after chronic consumption of ethanol. Arch Biochem Biophys 223: 425-432.

29) Brodie BB, Axelrod J. 1948. The estimation of acetanilide and its metabolic products, aniline, $N$-acetyl $p$ aminophenol and $p$-aminophenol (free and total conjugated) in biological fluids and tissues. J Pharmacol Exp Ther 94: 22-28.

30) Cai Y, Bennett D, Nair RV, Ceska O, Ashwood-Smith MJ, DiGiovanni J. 1993. Inhibition and inactivation of murine hepatic ethoxy- and pentoxy-resorufin odealkylase by naturally occurring coumarins. Chem Res Toxicol 6: 872-879.

31) Ko I-Y, Park SS, Song BJ, Patten C, Tan Y, Hah YC, Yang CS, Gelboin HV. 1987. Monoclonal antibodies to ethanol-induced rat liver cytochrome P-450 that metabolizes aniline and nitrosamines. Cancer Res 47: 3101-3109.

32) Park SS, Fujino T, West D, Guengerich FP, Gelboin HV. 1984. Monoclonal antibodies that inhibit enzyme activity of 3-methylcolanthene-induced cytochrome P450. Cancer Res 42: 1798-1808.

33) Omura T, Sato R. 1964. The carbon monooxide-binding pigment of liver microsomes. J Biol Chem 239: 2370-2378.

34) Gornall AG, Bardawill CJ, David MM. 1948. Determination of serum proteins by means of biuret reaction. J Biol Chem 177: 751-766.

35) Duncan DB. 1957. Multiple range tests for correlated and heteroscedastic means. Biometrics 13: 164-176.

36) Baraona E, Yokoyama A, Ishii H, Hernández-Muñoz R, Takagi T, Tsuchiya M, Lieber CS. 1991. Lack of alcohol dehydrogenase isoenzyme activities in the stomach of Japanese subjects. Life Sci 49: 1929-1934.

37) Asamoe L, Aarbakke J. 1999. Sex-dependent induction of alcohol dehydrogenase activity in rats. Biol Pharm 57: 1067-1072.

38) Chen L, Lee M, Hong J-Y, Huang W, Wang E, Yang CS. 1994. Relationship between cytochrome P450 2E1 and acetone catabolism in rats as studied with diallyl sulfide as inhibitor. Biochem Pharmacol $\mathbf{4 8}$ : 2199-2205.

39) Guengerich FP, Kim DH, Iwasaki M. 1991. Role of human cytochrome P-450 IIE1 in the oxidation of many low molecular weight cancer suspects. Chem Res Toxicol 4: 168-179.

40) Guengerich FP. 1988. Roles of cytochrome P-450 enzymes in chemical carcinogenesis and cancer chemotherapy. Cancer Res 48: 2946-2954.

41) Guengerich FP. 1991. Oxidation of toxic and carcinogenetic chemicals by human cytochrome P450 enzymes. Chem Res Toxicol 4: 391-407.

42) Fukunaga T, Sillanaukee P, Eriksson CJP. 1993. Occurrence of blood acetaldehyde in women during ethanol intoxication: preliminary findings. Alcohol Clin Exp Res 17: 1198-1200.

43) Yoshida A, Rzhetsky A, Hsu LC, Chang C. 1998. Human aldehyde dehydrogenase gene family. Eur $\mathrm{J}$ Biochem 251: 549-557.

44) Maly P, Crotet V, Sasse D. 1999. Spatial distribution of human liver aldehyde dehydrogenase isoenzymes. Histochem Cell Biol 111: 461-466.

45) Kunitoh S, Asai H, Imaoka S, Funae Y, Monna T. 1996. 
Metabolism of acetaldehyde to acetate by rat hepatic P450s: presence of different metabolic pathway from acetaldehyde dehydrogenase system. Alcohol Clin Exp Res 20 (1 Suppl): 22A-24A.

46) Matsunaga T, Iwawaki Y, Watanabe K, Yamamoto I, Kageyama T, Yoshimura H. 1996. Microsomal aldehyde oxygenase (MALDO): purification and characterization of a cytochrome $\mathrm{P} 450$ isozyme responsible for oxidation of 9-anthraldehyde to 9-anthracenecarboxylic acid in monkey liver. J Biochem 119: 617-625.
47) Terelius $\mathrm{Y}$, Norsten-Hoog C, Cronholm T, IngelmanSundberg M. 1991. Acetaldehyde as a substrate for ethanol-inducible cytochrome P450 (CYP2E1). Biochem Biophys Res Commun 179: 689-694.

48) Hannak D, Bartlet U, Kattermann R. 1985. Acetate formation after short-term ethanol administration in man. Biol Chem Hoppe-Seyler 366: 746-753.

49) Korri Um, Nuutinen H, Salaspiro M. 1985. Increased blood acetate: A new laboratory marker of alcoholism and heavy drinking. Alcohol Clin Exp Res 9: 468-471. 